\title{
A Comparative Study for the Development of Coal-to-Liquids Industries in China, South Africa and United States
}

\author{
Yiming Li ${ }^{1,2}$, Changqing $\mathrm{Li}^{1,2^{*}}$ \\ ${ }^{1}$ School of Chemical Engineering, Inner Mongolia University of Technology, Hohhot, China \\ ${ }^{2}$ School of Economics and Management, Inner Mongolia University of Technology, Hohhot, China \\ Email: li.yimingg@163.com, *nmgdlcq@163.com
}

How to cite this paper: Li, Y.M. and $\mathrm{Li}$, C.Q. (2019) A Comparative Study for the Development of Coal-to-Liquids Industries in China, South Africa and United States. Green and Sustainable Chemistry, 9, 85-93. https://doi.org/10.4236/gsc.2019.93006

Received: June 21, 2019

Accepted: August 2, 2019

Published: August 5, 2019

Copyright (๑) 2019 by author(s) and Scientific Research Publishing Inc. This work is licensed under the Creative Commons Attribution International License (CC BY 4.0).

http://creativecommons.org/licenses/by/4.0/

\begin{abstract}
Many energy consuming countries have carried out research, development, demonstration, planning and deployment of coal-to-liquids (CTL) because of its ability to replace oil imports by converting coal resources into fuel. Among them, China and South Africa successfully had their CTL technology industrialized, while the United States did not. To understand the differences in the industrial development level, a comparative study is necessary. This paper compares the history, driver and policy of CTL industry in China, South Africa and United States, collates and discloses numbers of industry details for the first time. We figure out that the motivation, top level planning and policy consistency are the key indicators of the difference on the industrial development level. Among them, the key to the success of CTL industrialization in China and South Africa is the government's strong and stable determination to improve energy security, which provides a stable top-level planning and robust policy support. The failure of CTL in United States is caused by the shift of policy attention after its energy security situation improved.
\end{abstract}

\section{Keywords}

Coal-to-Liquids, Comparative Study, China, United States, South Africa

\section{Introduction}

CTL is an oil alternative technology converting coal resources into fuel. According to the process, it can be divided into direct liquefaction path involving coal hydro-liquefaction [1], and indirect liquefaction path involving gasification and Fischer-Tropsch synthesis [2]. For net oil importers, CTL technology is a potential means to reduce oil import dependence and improve energy security. 
China, South Africa and the United States are the only three countries in the world to have developed commercial scale coal-to-liquids (CTL) plants. Among them, China and South Africa are success in the industrialization of CTL, but United States fails. A comparative study on the industrial history, driver and policy of CTL industry in three countries can help understand the differences in the development level of CTL industry and provide reference for the diffusion of other emerging energy industries.

Most existing articles explain the development level of CTL industry from the perspective of one country. For example, Vallentin, D. (2008) [9] analyzed the policy driving forces and obstacles to the development of CTL in the United States, and believed that the concern of the society and policy makers about global warming hindered the commercialization of CTL, so that this technology was only limited to the niche market such as military. Wu, N. (2011) [3] believes that the willingness of the Chinese government to maintain energy security and the impulse of business transformation of state-owned coal enterprises are the main driving forces for the industrialization of CTL in China. Nkomo, J. C. (2009) [4] and Hilsenrath, P. E. (1989) [8] revealed that energy security is the main driving force for CTL development in South Africa. In addition, Vallentin, d. (2008) [5] also analyzed the driving forces and obstacles of CTL development in Germany, and found that the country's climate change target and excessive investment in the project offset the improvement that CTL technology may bring to Germany's energy security.

\section{The Development and Positioning of CTL Industry in South Africa}

According to a report conducted by South Africa Department of Energy (DoE) in 2009 [6], two third of South Africa's liquid fuel is conversed from imported crude oil, one third is produced through CTL anf Gtl processes (Figure 1). Considering its limited oil and gas reserve, as well as the history of oil embargo, it is logic that South Africa government regards CTL technology as an important resource of liquid fuel [7]. Before 1949, the major pusher of CTL is the private sector. Anglovaal, a forward-looking coal company in South Africa, purchased the access of the Fischer-Tropsch technology from its German patent holder in 1936 [8]. After ten years' pushing and persuading, Anglovaal finally got powerful

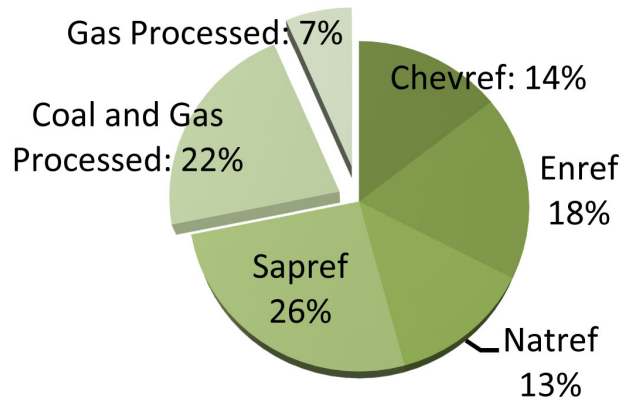

Figure 1. South Africa's liquid fuel supply. 
political supports. In the Liquid Fuel and Oil Act of 1947, the congress authorized the company to produce coal-based fuel not to exceed 13 million pounds, roughly accounting for $3 \%$ of the total designed plan of 76 million gallon per year [8].

In spite of supportive industrial policies, the private CTL companies still failed to lead the industry to take-off. In 1949, Anglovaal abandoned its construction plan of CTL plants, because of the revised capital cost and the opportunity cost resulted by new mineral deposit discoveries. One year later, believing that the government should play a more important role in accelerating the development of synfuel, a state-owned synthetic fuel company was established with the name of South Africa Synthetic Oil Limited (Sasol). In the next twenty years, Sasol has kept seeking technical cooperation with companies in Germany and U.S., as well as developing its own process and catalyst. Finding that the fluidized-bed process provided by Kellog, a US company, did not perform as promised, Sasol turned to its own fixed-bed technology developed since 1951. Self-owned catalyst producing process was successfully developed later, in 1969. In the first thirty years, Sasol has worked on accessing and testing technology and process, but not large-scale commercialization. Not until the oil embargo since 1974 and the later suspension of oil import from Iran in 1979, was Sasol willing to build several additional larger plants, each of which has an output of over 50,000 barrels a day [8].

To enter a certain industry, a common choice is to import technology. Following and observinge technologies in different countries over a long period of time are quite needed. It is not as easy as purchasing a device Unlike purchasing a device, it is not easy to test, to learn, to domesticate, and to scale up a new technology. The mature and various equipment/catalyst suppliers had made the solid institutional foundation of South Africa's CTL industry [7]. Different approaches including technology importing and independent developing became wise strategies to obtain reliable technologies. Finally, the independent way win the dominant position in South Africa since it is much more reliable and suitable for domestic market. Despite the promising future of fluidized bed, the conservative option is preferred by the government because of the vast initial funding and high risks of CTL technology. At last, a series of external events had driven the government to take actions to meet the strategic demand, so that the CTL technology can be industrialized on a large scale.

\section{The Development and Positioning of CTL Industry in United States}

Since $19^{\text {th }}$ century, coal gasification technology has been widely used for town gas in U.S and Europe, which laid a solid institutional and industrial foundation for the emerging of F-T technology [7]. Realized the important role liquid fuel will play in mechanized warfare, the US Congress appropriated 30 million dollars to the Bureau of Mine successively in 1944 and 1948, in order to build three 
CTL facilities. However, being obstructed by the petroleum sector, the 8-billiondollar synthetic fuel program was cut down by the DOD for lacking of economic viability. As the second wave of American CTL technology development, the Office of Coal Research (OCR) came up with six pilot projects to help coal states to pull through in 1960s. But due to technology, economy and risk factors, these efforts finally all turned out to be in vain.

The following decade is the hard period, in which the two waves of Oil Crisis in 1976 and 1979 made the policymakers realize the importance of oil independence. The legitimacy of CTL technology was thus enhanced so that the US government restarted the CTL program with a R\&D fund of 1.7 billion dollars. Eight separate CTL plants, including the famous Great Plains Gasification Plant, had been established since 1975 [9]. In 1980, a state-owned firm (US Synthetic Fuels Corporation) was authorized by the Congress to develop synthetic fuel technology. Up to 17 billion dollars was approved as the first-four-year budget for this company. Since the oil price smoothed down in 1981, and the capital demand was growing rapidly in construction period, the company finally lost its financial supports. The whole CTL industry in US ended up in demonstration stage because the private sections were facing much more severe tests of financial pressures and risks, so it was harder for them to get any progress.

Unlike South Africa, the US CTL Industry was facing huge resistance from the Petroleum Industry since the very beginning. South Africa had very low oil reserves, and the oil refineries which dealing with the imported oil had tried their best yet hardly to meet domestic oil demand [6]. So CTL technology was never considered a threat or substitute to the Petroleum Industry. Meanwhile, the interest groups of Petroleum Industry in US had sufficient motivations and capabilities to obstruct the development of CTL Industry.

Just as South Africa did in 1950, US built its first state-owned CTL plant in 1980. In a conservative nation, taking actions to expand public sector's powers like starting government regulations and establishing state-owned corporations have always been difficult attempts. The reason why US Congress approved above decisions is most likely that only a state-owned corporation can bear the extremely large strategic externalities, capital investments and operational risks. The Congress realized it is the only way to develop CTL Industry. After experienced two oil crises, the driving force to build independent liquid fuel supply in US had become explicit. But different from South Africa in 1970s, US never faced actual threat of oil cut-off. With the oil price stabilized later, CTL Industry (which is still in demonstration period) was questioned by the Congress, and finally failed to achieve commercialization. The drop of planning CTL scale between 2008 and 2014 is demonstrated in Table 1.

Since 1970s, the US Government has set the energy independence as a national policy. In recent years, US has become more and more self sufficient on its energy supplies. For decades, the revolutions on Shale Oil and Gas once seemed impossible have almost come true. 
Table 1. The planning scale of commercial projects in US (2008 and 2014).

\begin{tabular}{|c|c|c|}
\hline Affiliation & Location & Capacity \\
\hline US Air Force & Malmstrom AFB, MT & $20-30,000 \mathrm{Bpd}$ \\
\hline Rentech/Peabody & MT & $10-30,000 \mathrm{Bpd}$ \\
\hline Headwaters/Consol & WY & N/A \\
\hline DKRW/GE/ExxonMobil & Medicine Bow, WY & $20,000 \mathrm{Bpd}$ \\
\hline Headwaters/NACC/GRE & ND & $32,000 \mathrm{Bpd}$ \\
\hline American Clean Coal Fuels & Oakland, IL & $25,000 \mathrm{Bpd}$ \\
\hline Rentech/Peabody & IL, IN, KY & $10-30,000 \mathrm{Bpd}$ \\
\hline Fuel Frontiers Inc/Westinghouse & Muhlenberg Co. KY & 13,000 Bpd \\
\hline Rentech & IL & $1800 \mathrm{Bpd}$ \\
\hline Silverado Green Fuel Inc./MS & Choctaw Co., MS & N/A \\
\hline Rentech/Adams Co. & Natchez, MS & $1600 / 20,000 \mathrm{Bpd}$ \\
\hline Synfuel, Inc./GE/Haldoe-Topsoe/NACC/Exxon Mobil & Ascension Parish, LA & N/A \\
\hline AIDEA/ANRTL/CPC & Cook Inlet, AK & $80,000 \mathrm{Bpd}$ \\
\hline Total Capacity announced in 2008 & & at least $281,800 \mathrm{Bpc}$ \\
\hline Affiliation & Location & Capacity \\
\hline Trans Gas Development Systems (TGDS) & Mingo County, WV & $18,000 \mathrm{Bpd}$ \\
\hline USA Synthetic Fuel Corp. (USASF) & WY & N/A \\
\hline Fairbanks Economic Development Corp. (FEDC) & Fairbanks, AK & $\sim 40,000 \mathrm{Bpd}$ \\
\hline Freedom Energy Diesel LLC & Morristown, TN & N/A \\
\hline Future Fuels, Kentucky River Properties & Perry County, KY & N/A \\
\hline $\begin{array}{l}\text { Australian-American Energy Co. } \\
\text { (Terra Nova Minerals or Great Western Energy), Crow Nation }\end{array}$ & Big Horn County, MT & $8000 \mathrm{Bpd}$ \\
\hline MidAmericaC2L/Siemens & McCracken County, KY & $10,200 \mathrm{Bpd}$ \\
\hline Accelergy, Tyonek Native Corporation & Cook Inlet, AK & $60,000 \mathrm{Bpd}$ \\
\hline US Fuel Corporation & KY & $525 \mathrm{Bpd}$ \\
\hline Total Capacity announced in 2014 & & at least $136,700 \mathrm{Bpc}$ \\
\hline
\end{tabular}

\section{The Development and Positioning of CTL Industry in China}

How far the CTL can go as a strategic industry depends on the situation of national energy security. In the last 30 years, insecurity of liquid fuel supply has been the most alarming problem for Chinese leaders, although the rest of the challenges, for example, imbalance of energy distribution, low energy efficiency, and massive pollution, are still noticeable in energy sector. Lacking of availability, reliability and affordability of oil [10] seriously threats Chinese government's fulfillment to its commitment on improving living level, accelerating economy development, safeguarding sovereignty and territory, and realizing the national rejuvenation [11]. 
Confronting the challenge of energy insecurity since 1993, Chinese government put its attention on coal-to-liquids (CTL) technology, known as a modern coal-chemical method conversing domestic coal into synthetic liquid fuels. After almost 20 years examining and testing, five projects were approved in 2007 to test or demonstrate the technology in industrial scale. However, the industry misunderstood these projects as a sign of encouraging large-scale commercialization. Local government started to put CTL plants in their "five-year plans", and enterprises rush into this "clean coal" industry. In 2012, the total capacity of planned projects reached 50 million tons per year, accounting for $10 \%$ of oil imports at that time.

Since the $21^{\text {st }}$ century, CTL technology has been highly valued by policymakers in China. It is considered a mature technology with relatively low environmental costs and favorable high additional industrial values. By October 2016, China's total operational CTL capacity has been reached 7.9 million tons, and will come to 18.78 million tons annually by 2018 in the plan. But for a number of reasons including oil price downward, environment policy tightening, exposed technical problems and alternative energy sources, CTL technology is losing its competitiveness in economic value, risk managing capacity and environmental impact.

\section{Comparison Analysis: What Made the Differences between Winner and Loser in Diffusion?}

\subsection{Motivation}

National energy security is the primary motivation for the development of CTL (Figure 2). With 2006 as a turning point, South Africa and China were significantly motivated due to the increasing reliance of oil imports, while the United States abandoned CTL because of improved energy security.

\subsection{Top Level Planning}

CTL is an industry with strategic positive externalities and environmental negative externalities, so public sector intervention is necessary. Lack of top-level industrial planning, will lead to the failure in establishing sector expectation, and may either cause stalled development or disorderly development.

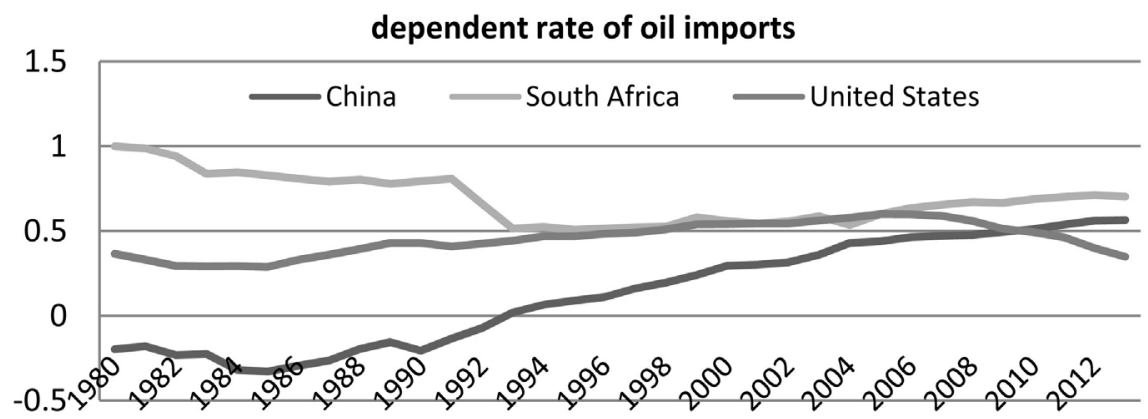

Figure 2. Dependence rate of oil imports in China, South Africa and United States. 
Although the administrative planning scale of China's CTL industry has been adjusted several times, the development direction and planning are stable. By 2020, the actual scale of coal-to-liquids in China will reach 13 million tons per year, basically in line with the medium-term plan formulated in 2014 and 2016 (Table 2). However, there is no CTL capacity planning at the federal level in US, and the scale of business planning was also shrinking. As the dependence of U.S. oil imports decreased from $56.08 \%$ in 2008 to $26.33 \%$ in 2014, CTL's importance and competitiveness declined rapidly, dampening the enthusiasm for technological development. In 2014, the total production of announced commercial-scale CTL plants in U.S. fell to less than half of that in 2008 (Table 2).

\subsection{Policy Consistency}

The support policies for CTL industry in the three countries are all intensive and powerful. But the success of CTL industry in China and South Africa has been helped by a series of stable supportive policies, while US has a serious problem of policy inconsistency (Table 3). For instance, in 2008, the positive attitude of the federal and provincial governments encouraged the industry planning new plants. However, the financial supports didn't last long. As a result, many projects have run into financial difficulties. And soon, most of these plants are canceled or delayed.

\section{Conclusions}

By comparing the development history, driving force and supporting policies of CTL industry in China, South Africa and the United States, we identify the main factors leading to the different development levels of the three countries lie in the motivation, top level planning and policy consistency. Among them, the key to the success of CTL industrialization in China and South Africa is the government's strong and stable determination to improve energy security, which provides

Table 2. Planning scale of commercial-sized CTL plants in China, South Africa and United States.

\begin{tabular}{|c|c|c|c|c|c|c|c|c|c|c|c|c|}
\hline Country & Year & 2008 & 2009 & 2010 & 2013 & 2014 & 2015 & 2017 & 2020 & 2030 & $\begin{array}{l}\text { CTL proportion } \\
\text { in oil demand }\end{array}$ & $\begin{array}{l}\text { dependence rate } \\
\text { of imported oil }\end{array}$ \\
\hline \multirow{4}{*}{ China } & plan in 2006 & & & 150 & & & 1000 & & 3000 & & $4.93 \%$ & $46.37 \%$ \\
\hline & plan in 2014 & & & & & & & 1000 & & & $1.74 \%$ & $56.48 \%$ \\
\hline & plan in 2016 & & & & & & & & 1200 & & $1.97 \%$ & $63.50 \%$ \\
\hline & actual capacity & 100 & 155 & 155 & 155 & 162 & 311 & 711 & 1300 & & $2.13 \%$ & $63.50 \%$ \\
\hline \multirow{3}{*}{ U.S. } & plan in 2008 & & & & & & & & & 14,900 & $15.00 \%$ & $59.05 \%$ \\
\hline & $\begin{array}{c}\text { announced } \\
\text { capacity (2008) }\end{array}$ & 1409 & & & & & & & & & $1.45 \%$ & $56.08 \%$ \\
\hline & $\begin{array}{c}\text { announced } \\
\text { capacity (2014) }\end{array}$ & & & & & 680 & & & & & $0.71 \%$ & $26.33 \%$ \\
\hline $\begin{array}{l}\text { South } \\
\text { Africa }\end{array}$ & actual capacity & 800 & 800 & 800 & 700 & N/A & N/A & & & & $29.74 \%$ & $70.26 \%$ \\
\hline
\end{tabular}


Table 3. Types and cases of subsidies to CTL industry in China, South Africa and United States.

\begin{tabular}{|c|c|c|c|}
\hline Support & China & United States & South Afreica \\
\hline $\begin{array}{l}\text { Operating } \\
\text { concessions }\end{array}$ & $\begin{array}{l}\text { The ministry of commerce granted the } \\
\text { wholesale operation qualification of refined } \\
\text { oil to } 3 \text { CTL enterprises in } 2009 \text { and } 2010\end{array}$ & - & $\begin{array}{l}\text { In 1947, the South African } \\
\text { government allocated liquid fuel } \\
\text { production licenses to Anglovaal } \\
\text { Since 1954, the South African } \\
\text { government has required all } \\
\text { gas stations to have Sasol pumps } \\
\text { (the Blue Pump). }\end{array}$ \\
\hline Joint venture & $\begin{array}{l}\text { Most CTL enterprises } \\
\text { such as shenhua, yankuang and } \\
\text { lu'an are state-owned enterprises }\end{array}$ & $\begin{array}{l}\text { In 1975, the United States government } \\
\text { participated in the investment of the } \\
\text { great plain CTG project. In 1980, the } \\
\text { state-owned United States synthetic } \\
\text { oil company was established to } \\
\text { direCTLy invest in the construction of } \\
\text { CTL projects. In 2007, the U.S. air } \\
\text { force invested in the construction } \\
\text { of a } 1.5 \mathrm{Mt} / \mathrm{a} \text { CTL plant at } \\
\text { Malmstrom air force base }\end{array}$ & $\begin{array}{l}\text { Sasol, a state-owned CTL } \\
\text { company founded by the South } \\
\text { African government in } 1950, \\
\text { now operates the largest scale } \\
\text { of CTL project in the world }\end{array}$ \\
\hline Direct subsidy & $\begin{array}{l}\text { In 1998, the state council of China } \\
\text { allocated } 11 \text { billion Yuan of } \\
\text { coal-replacing-oil fund to Shenhua. } \\
\text { R \& d grants from MOST, } \\
\text { NDRC and NSFC }\end{array}$ & $\begin{array}{l}\text { Since } 2007 \text {, the U.S. government } \\
\text { has allocated } \$ 8 \text { billion to various } \\
\text { coal-power and gasification projects. } \\
\text { In } 2016 \text {, the US Navy, DOE and } \\
\text { USDA allocated } 210 \text { Million USD } \\
\text { to three BTL companies }\end{array}$ & $\begin{array}{l}\text { Since 1989, the South African } \\
\text { government has allocated a } \\
\text { total of R6 billion to SASOLouth } \\
\text { Africa continues to subsidize } \\
\text { production for all refiners. } \\
\text { The South African government } \\
\text { has subsidised Sasol's } \\
\text { production of CTL with } \\
\text { petrol taxes since } 1970\end{array}$ \\
\hline $\begin{array}{l}\text { government } \\
\text { purchases }\end{array}$ & $\begin{array}{l}\text { The logistics department of the Chinese } \\
\text { air force tested Shenhua CTL as jet fuel } \\
\text { (2012); China aerospace science and } \\
\text { technology corporation tests Shenhua } \\
\text { coal-based rocket fuel (2015) }\end{array}$ & $\begin{array}{l}\text { In 2006, Edward air force base } \\
\text { purchased Syntroleum's coal-based } \\
\text { synthetic oil to test jet fuel. US Great } \\
\text { Green Fleet purchases } \\
\text { biofuels in } 2013 \text { and } 2016\end{array}$ & $?$ \\
\hline loan guarantee & $\begin{array}{l}\text { Preferential loans from China development } \\
\text { bank for key CTL projects; State-owned } \\
\text { Banks guarantee loans for coal-to-oil } \\
\text { projects. }\end{array}$ & $\begin{array}{l}\text { In } 2005 \text {, the U.S. government began } \\
\text { offering loan guarantees for } \\
\text { commercialization of new energy } \\
\text { technologies, including CTL }\end{array}$ & $?$ \\
\hline Tax breaks & $\begin{array}{l}\text { In } 2017 \text {, the Ningxia government applied to } \\
\text { the central government for reduction of } \\
\text { consumption tax on refined oil products } \\
\text { for the CTL demonstration project }\end{array}$ & $\begin{array}{l}\text { From } 2005 \text { to } 2009 \text {, the U.S. government } \\
\text { granted tax breaks for alternative fuels }\end{array}$ & $?$ \\
\hline Tariff & No & No & fuel tariffs \\
\hline $\begin{array}{l}\text { Mineral resource } \\
\text { allocation }\end{array}$ & $\begin{array}{l}\text { Since 2004, the Chinese government } \\
\text { has given priority of coal } \\
\text { resources to CTL industry }\end{array}$ & No & No \\
\hline
\end{tabular}

a stable top-level planning and robust policy support. The failure of CTL in United States is caused by the shift of policy attention after its energy security situation improved.

We believe that comparative policy studies between countries can help to establish a theoretical framework for the diffusion of emerging energy technolo- 
gies. At present, there are few alternatives for similar frameworks, mainly innovation system theories represented by the Technological Innovation System (TIS) [12] and the Strategic Niche Management (SNM) system [13]. In the future, the authors will further develop the three policy indicators proposed in this paper and integrate them into an interpretation theory specifically for fossil energy industry.

\section{Conflicts of Interest}

The authors declare no conflicts of interest regarding the publication of this paper.

\section{References}

[1] Kejian, L., et al. (2015) Study and Development of Shenhua Direct Coal Liquefaction Technology. Clean Coal Technology, 21, 50-55.

[2] Xiang, H., Yang, Y. and Li, Y. (2014) Indirect Coal-to-Liquids Technology from Fundamental Research to Commercialization. Scientia Sinica Chimica, 44, 1876.

[3] Wu, N. (2011) China Energy Issues: Energy Intensity, Coal Liquefaction, and Carbon Pricing. Massachusetts Institute of Technology. http://hdl.handle.net/1721.1/68884

[4] Nkomo, J. C. (2009) Energy Security and Liquid Fuels in South Africa. Journal of Energy in Southern Africa, 20, 20-24. https://doi.org/10.17159/2413-3051/2009/v20i1a3298 http://www.scielo.org.za/pdf/jesa/v20n1/03.pdf

[5] Vallentin, D. (2008) Driving Forces and Barriers in the Development and Implementation of Coal-to-Liquids (CtL) Technologies in Germany. Energy Policy, 36, 2030-2043.

[6] Trollip, H., et al. (2014) Energy Security in South Africa. Mitigation Action Plans and Scenarios (MAPS), No. 17, 45.

[7] Bartis, J.T., Camm, F. and Ortiz, D.S. (2008) Producing Liquid Fuels from Coal. RAND Corporation, Santa Monica, CA.

[8] Hilsenrath, P.E. (1989) The Development of Synthetic Fuels in South Africa. The Journal of Energy and Development, 14, 269-283.

[9] Vallentin, D. (2008) Policy Drivers and Barriers for Coal-to-Liquids (CtL) Technologies in the United States. Energy Policy, 36, 3188-3201.

[10] Kong, B. (2005) An Anatomy of China's Energy Insecurity and Its Strategies. Pacific Northwest National Laboratory, US Department of Energy.

[11] Yergin, D. (1988) Energy Security in the 1990s. Foreign Affairs, 67, 110-132. https://doi.org/10.2307/20043677

[12] Bergek, A., Jacobsson, S., Carlsson, B., Lindmark, S. and Rickne, A. (2008) Analyzing the Functional Dynamics of Technological Innovation Systems: A Scheme of Analysis. Research Policy, 37, 407-429. https://doi.org/10.1016/j.respol.2007.12.003

[13] Kemp, R., Schot, J. and Hoogma, R. (1998) Regime Shifts to Sustainability through Processes of Niche Formation: The Approach of Strategic Niche Management. Technology Analysis \& Strategic Management, 10, 175-198.

https://doi.org/10.1080/09537329808524310 